\title{
PENGARUH MODEL PEMBELAJARAN BERBANTUAN \\ APLIKASI GOOGLE CLASSROOM TERHADAP HASIL BELAJAR BOLA BASKET
}

\author{
Harry Fitriyanto ${ }^{1}$, I Ketut Sudiana ${ }^{2}$, Made Agus Wijaya ${ }^{3}$ \\ ${ }^{1}$ Program Studi Pendidikan Olahraga, Program Pascasarjana- \\ Universitas Pendidikan Ganesha, Singaraja-Bali \\ ${ }^{2}$ Program Studi Penjaskesrek, Universitas Pendidikan Ganesha \\ Singaraja-Bali \\ ${ }^{2}$ Program Studi Penjaskesrek, Universitas Pendidikan Ganesha \\ Singaraja-Bali \\ e-mail: harryrachman.id@gmail.com, ketut.sudiana@undiksha.ac.id, \\ wijaya.madeagus@undiksha.ac.id
}

\begin{abstract}
Abstrak
Penelitian ini bertujuan untuk mengetahui perbedaan hasil belajar bola basket antara siswa yang mengikuti model pembelajaran kooperatif tipe STAD dengan siswa yang mengikuti model pembelajaran PBL berbantuan aplikasi google classroom. Penelitian ini merupakan true experiment dengan rancangan The randomized pretest-posttest control group the same subjec design. Populasi penelitian seluruh siswa kelas VII SMP Negeri 1 Negara, sampel berjumlah 72 siswa. Penetapan sampel dengan teknik random sampling. Pengumpulan data menggunakan nilai keterampilan teknik dasar bola basket (dribbling, shoting, passing). Data yang diperoleh dianalisis menggunakan uji ANAVA. Pada kelompok yang dibelajarkan dengan model pembelajaran kooperatif tipe STAD berbantuan aplikasi google classroom diperoleh nilai rata-rata 86,2 dengan standar deviasi 1,35. Sedangkan pada kelompok yang dibelajarkan dengan model pembelajaran PBL berbantuan aplikasi google classroom. diperoleh nilai rata-rata 81,8 dengan standar deviasi 1,09. Angka signifikansi yang diperoleh melalui Uji t adalah 0,040. Berdasarkan hasil analisa data dan pembahasan, simpulan penelitian ini adalah bahwa terdapat perbedaan pengaruh hasil belajar bola basket pada siswa yang mengikuti pembelajaran kooperatif tipe STAD berbantuan aplikasi google classroom lebih tinggi dari pada siswa yang mengikuti model pembelajaran PBL berbantuan aplikasi google classroom.
\end{abstract}

Kata-kata kunci : STAD, PBL, Google Classroom

\begin{abstract}
This study aims to determine differences in basketball learning outcomes between students who take the STAD type cooperative learning model aided by the google classroom application and students who take the PBL learning model aided by the google classroom application. This research is a true experiment with the randomized pretest-posttest control group design the same subject design. The study population was all eighth grade students of SMP Negeri 1 Negara, a sample of 72 students. Determination of the sample by random sampling technique. Data collection uses the
\end{abstract}


value of basic basketball technical skills (dribbling, shoting, passing). The data obtained were analyzed using the ANAVA test. In the group learned with the STAD type cooperative learning model aided by the google classroom application, an average score of 86.2 with a standard deviation of 1.35 was obtained. Whereas the groups that are taught using the PBL learning model are assisted by the Google classroom application. an average value of 81.8 is obtained with a standard deviation of 1.09. The significance value obtained through the test was 0.040. Based on the results of data analysis and discussion, the conclusion of this study is that there are differences in the effect of basketball learning outcomes on students who take STAD type cooperative learning assisted by the Google classroom application is higher than students who take the PBL learning model aided by the Google classroom application.

Keywords: $\quad$ STAD, PBL, Google Classroom

\section{PENDAHULUAN}

$\begin{array}{cccc} & \text { Pendidikan } & \text { mempunyai } & \text { peran } \\ \text { yang } & \text { sangat } & \text { penting } & \text { dalam }\end{array}$ meningkatkan kualitas sumber daya manusia dan upaya mewujudkan citacita bangsa Indonesia untuk mewujudkan kesejahteraan umum dan mencerdaskan kehidupan bangsa. Oleh karena itu, pendidikan bagi kehidupan umat manusia merupakan kebutuhan yang dipenuhi sepanjang hayat. Menurut Undang-Undang Republik Indonesia Nomor 20 Tahun 2003 tentang Sistem Pendidikan Nasional Bab II Pasal 3 disebutkan bahwa, pendidikan nasional berfungsi mengembangkan kemampuan dan membentuk watak serta peradaban bangsa yang bermartabat dalam rangka mencerdaskan kehidupan bangsa, bertujuan untuk berkembangnya potensi peserta didik agar menjadi manusia beriman bertakwa kepada Tuhan Yang Maha Esa, berakhlak mulia, sehat, berilmu, cakap, kreatif, mandiri, dan menjadi warga Negara yang demokratis serta bertanggung jawab.

Dalam proses pembelajaran pengembangan potensi-potensi peserta didik harus dilakukan secara menyeluruh dan terpadu. Proses pembelajaran di kelas, guru tidak cukup hanya berbekal pengetahuan berkenaan dengan bidang studi yang diajarkan, akan tetapi perlu memperhatikan aspekaspek pembelajaran yang mendukung terwujudnya pengembangan potensi peserta didik.

Permasalahan yang sering dijumpai dalam pembelajaran pendidikan jasmani, olahraga dan kesehatan (PJOK) di sekolah yaitu rendahnya minat dan aktifitas belajar peserta didik sehingga hasil belajar peserta didik kurang tercapai optimal. Para peserta didik tidak mampu membagi waktu bermain dengan belajar sehingga aktivitas belajar sangat kurang. Dan juga peserta didik tidak mempunyai motivasi dari diri sendiri untuk belajar sehingga hasil belajar tetap bahkan menurun. Tidak adanya interaksi antara peserta didik dalam membahas sesuatu materi pelajaran.

Namun, realitanya proses pembelajaran yang terjadi dilapangan guru lebih cenderung menggunakan model pembelajaran konvensional dan kurangnya penggunaan media pembelajaran dalam proses pembelajaran yang membuat suasana pembelajaran kurang menarik. Dan guru dalam memberikan materi lebih sering menggunakan cara ceramah atau disebut dengan transfer ilmu dari guru kesiswa tanpa adanya feed back dari siswa, oleh karena itu model pembelajaran seperti ini cenderung mengajarkan siswa hanya 
untuk mendengarkan tanpa adanya usaha untuk menggali pengetahuannya sendiri dan belajar untuk berpikir kritis dalam menghadapi suatu permasalahan.

Kualitas proses pembelajaran menentukan hasil belajar, oleh karena itu proses pembelajaran harus dirancang untuk mampu mengembangkan hasil belajar yang diperlukan peserta didik. Dimyati dan Mudjiono (2006:295) menyatakan bahwa "dampak pengajaran adalah hasil yang dapat diukur dengan segera atau secara langsung, sedangkan dampak pengiring adalah hasil belajar siswa yang tampak secara tidak langsung atau merupakan transfer hasil belajar".

Solusi untuk meningkatkan hasil belajar peserta didik, perlu dilakukan peningkatan kualitas pembelajaran. Kualitas pembelajaran tersebut terdiri dari ranah afektif, ranah kognitif, dan ranah psikomotor. Peserta didik mampu memahami teori yang diberikan oleh guru serta mampu menerapkan dalam kehidupan sehari-hari. Dalam hal ini peneliti memberikan alternatif pemecahan masalah untuk mengatasi situasi tersebut, yaitu dengan menerapkan model pembelajaran kooperatif tipe Students Teams Achievement Divison (STAD) dan model pembelajaran Problem Based Learning (PBL). Kedua model pembelajaran tersebut dapat digunakan dalam mengatasi permasalahan di atas karena model pembelajaran ini menuntut peserta didik untuk mau mengajukan permasalahan yang dihadapi, bekerjasama, berdiskusi dan berinteraksi dengan anggota kelompoknya masing-masing.

Model pembelajaran kooperatif tipe STAD salah satu metode pembelajaran yang dikembangkan oleh Robert E. Slavin yang menekankan adanya aktivitas dan interaksi di antara siswa untuk saling memotivasi dan saling membantu dalam menguasai materi pelajaran guna mencapai prestasi yang maksimal. Jadi, tekanan utama metode ini adalah keberhasilan target kelompok dengan asumsi bahwa target hanya dapat dicapai jika setiap anggota tim berusaha menguasai subyek yang menjadi bahasan. Sedangkan Menurut Nurhadi, dkk (2004: 56) PBL adalah suatu pendekatan pengajaran yang menggunakan masalah dunia nyata sebagai suatu konteks bagi siswa untuk belajar tentang cara berpikir kritis dan keterampilan pemecahan masalah, serta untuk memperoleh pengetahuan dan konsep yang esensial dari materi pelajaran. Jadi model pembelajaran STAD atau model PBL sehingga dengan penerapan model pembelajaran tersebut diharapkan dapat membuat peserta didik lebih tertarik pada pembelajaran dan tidak jenuh dengan pembelajaran sebelumnya. Selain itu, dari hasil pengamatan awal menunjukan bahwa motivasi dan keaktifan belajar peserta didik terlihat kurang, kemampuan diskusi peserta didik rendah sehingga mengakibatkan kemampuan berpikir kritis dan keterampilan perserta didik menjadi rendah.

Langkah-langkah model pembelajaran kooperatif tipe STAD ada 6, yaitu : 1) Menyampaikan tujuan pembelajaran dan mempersiapkan siswa, 2) Menyajikan informasi, 3)Mengorganisasikan siswa kedalam kelompok-kelompok belajar, 4)Membimbing kelompok bekerja dan belajar, 5) Evaluasi dan 6) Memberikan penghargaan.

Model PBL merupakan suatu model pembelajaran yang difokuskan pada pengalaman pembelajaran yang diatur meliputi penyelidikan dan pemecahan masalah khususnya masalah yang berkaitan dengan kehidupan sehari-hari. 
Model pembelajaran
merupakan salah satu model
pembelajaran yang berasosiasi dengan
pembelajaran kontekstual. Pembelajaran
artinya dihadapkan pada suatu masalah,
yang kemudian dengan melalui
pemecahan masalah, melalui masalah
tersebut siswa belajar keterampilan-
keterampilan yang lebih mendasar.
Menurut Adiwiguna (2019:96),
mengemukakan bahwa PBL membantu
meningkatkan perkembangan
ketrampilan belajar sepanjang hayat
dalam pola pikir yang terbuka, reflektif,
kritis, dan belajar aktif. PBL menekankan belajar sebagai proses yang melibatkan pemecahan masalah dan berpikir kritis dalam konteks yang sebenarnya, Sudiasih (2018:74). Model PBL merupakan pembelajaran yang penyampaiannya dilakukan dengan cara menyajikan suatu permasalahan yang kontekstual yang ditemukan oleh siswa dalam kehidupan sehari-hari dan bermakna yang dapat memberikan kemudahan kepada mereka untuk melakukan penyelidikan (Wirata 2019:140). Berdasarkan pendapatpendapat dari para ahli di atas, maka dapat disintesiskan bahwa model PBL merupakan pembelajaran yang penyampaiannya dilakukan dengan cara menyajikan suatu permasalahan konstektual terkait dengan kompetensi dasar yang sedang dipelajari oleh siswa yang ditemukan oleh siswa dalam kehidupan sehari-hari.

Langkah-langkah model pembelajaran PBL ada 5, yaitu : 1) Orientasi siswa pada masalah, 2) Mengorganisasi siswa untuk belajar, 3) Membimbing penyelidikan individual maupun kelompok, 4) Mengembangkan dan menyajikan hasil karya, dan 5) Menganalisis dan mengevaluasi proses pemecahan masalah. Dengan demikian dapat disimpulkan bahwa langkahlangkah model Problem Based Learning adalah organisasi konsep atau masalah, mengorganisasi siswa belajar, membimbing siswa dalam mencari informasi, mengembangkan dan menyajikan hasil karya, serta menganalisis dan mengevaluasi proses pemecahan masalah.

Salah satu ruang lingkup pembelajaran PJOK di sekolah yaitu hasil belajar bola bakset yang meliputi: dribbling, shooting, dan passing. Menurut Ahmadi (2007:2) permainan yang sederhana, mudah dipelajari dan dikuasai dengan sempurna yang juga menuntut perlunya melakukan suatu latihan baik (disiplin) dalam rangka pembentukan kerja sama tim. Permainan ini juga menyuguhkan kepada penonton banyak hal seperti dribbling sembari meliuk-liuk dengan lincah, tembakan yang bervariasi, terobosan yang fantastik, gerakan yang penuh tipu daya dan silih bergantinya mencetak poin dari regu yang bertanding.

Hasil belajar adalah suatu proses yang dilakukan individu untuk memperoleh suatu perubahan tingkah laku yang baru secara keseluruhan, sebagai hasil pengalaman individu itu sendiri di dalam interaksi dengan lingkungannya (Adnyani, 2017:80). Hasil belajar adalah hasil yang dicapai siswa dalam bentuk angka-angka setelah diberikan suatu tes hasil belajar pada akhir suatu pertemuan, pertengahan semester maupun akhir semester.

Dengan berakhirnya suatu proses belajar, maka siswa memperoleh suatu hasil belajar. Hasil belajar merupakan hasil dari suatu interaksi tindak belajar dan tindak mengajar. Hasil belajar tersebut dapat dibedakan menjadi dampak pengajaran dan dampak pengiring. Dimyati dan Mudjiono, (2006:295) menyatakan bahwa "dampak pengajaran adalah hasil yang 
dapat diukur dengan segera atau secara langsung, sedangkan dampak pengiring adalah hasil belajar siswa yang tampak secara tidak langsung atau merupakan transfer hasil belajar". Peneliti menyimpulkan bahwa hasil belajar adalah hasil yang dicapai siswa dalam bentuk angka-angka setelah diberikan suatu tes hasil belajar pada akhir suatu pertemuan, pertengahan semester maupun akhir semester.

Berdasarkan data studi dokumentasi hasil tes akhir semester I siswa kelas VII SMPN 1 Negara tahun pelajaran 2019/2020 khususnya pada mata pelajaran PJOK bahwa rata-rata hasil tes ulangan harian I kelas VII SMPN 1 Negara ditemukan hasil ulangan siswa masih dibawah KKM. Melihat hasil belajar yang masih rendah seperti maka harus dicari akar penyebabnya. Kesenjangan yang terjadi antara upaya dan kenyataan disebabkan oleh beberapa faktor yang mengakibatkan menurunnya kualitas pendidikan. Salah satu isu yang paling penting dalam pengembangan kualitas pendidikan adalah adanya peran guru dalam mengaplikasikan model pembelajaran di kelas yang kurang menekankan kemampuan berpikir siswa yang menyebabkan hasil belajar siswa masih kurang.

Berdasarkan penelitian yang dilakukan oleh 1) Haryanto (2015) menemukan bahwa, terdapat pengaruh yang signifikan penerapan model pembelajaran kooperatif tipe STAD berbantuan video animasi terhadap hasil belajar siswa kelas VII SMPLB C Negeri denpasar. Hal ini ditunjukkan dengan nilai t hitung lebih besar dari pada $\mathrm{t}$ tabel $(\mathrm{t}$ hitung $=2,586>$ ttabel $=$ 2,262). 2) Swadesi (2018) menemukan bahwa, terdapat peningkatan kualitas pembelajaran dengan menggunakan media pembelajaran PJOK berbasis ICT di SMP, hasil yang menunjukkan bahwa uji coba model pembelajaran ini efektif dengan nilai skor rata-rata 4,349 (skala 5) dan dikategorikan "Sangat Baik". Data ini mencerminkan bahwa pemanfaatan ICT berperan penting terhadap kualitas pembelajaran. Yudani (2016) menemukan bahwa, terdapat peningkatan hasil belajar IPA setelah diterapkan model pembelajaran Problem Based Learning (PBL) berbantuan media Questions Box pada siswa kelas IV semester II di SD Negeri 4 Tulamben. Sedangkan, Fatoni (2016) menemukan bahwa, terdapat pengaruh Pembelajaran Kooperatif Tipe STAD dengan Strategi Problem Based Learning Terhadap Kerjasama dan Hasil Belajar IPS Siswa Kelas V SD, Novriyanti (2014), menemukan bahwa, terdapat pengaruh model pembelajaran Problem Based Learning terhadap hasil belajar siswa pada materi pokok suhu dan kalor di kelas X SMA Negeri 1 Delitua, dengan nilai rata-rata posttest kelas eksperimen 71,63 dan kelas kontrol 67,48.

Berdasarkan uraian diatas peneliti berkeinginan meneliti dengan judul: "Pengaruh Model Pembelajaran Kooperatif Tipe STAD dan Model Pembelajaran PBL berbantuan aplikasi google classroom Terhadap Hasil belajar bola basket kelas VII SMPN 1 Negara."

\section{METODE}

Jenis eksperimen pada penelitian ini yaitu true eksperiment. Penelitian ini dilakukan untuk mengetahui Pengaruh Model Pembelajaran Kooperatif Tipe STAD dan Model Pembelajaran PBL berbantuan aplikasi google classroom Terhadap Hasil belajar bola basket kelas VII SMPN 1 Negara. Dengan demikian rancangan analisis data penelitian yang digunakan adalah The randomized pretest-posttest control group the same subjec design (Emzir, 2008). Populasi 
dalam penelitian ini adalah seluruh peserta didik kelas VII SMPN 1 Negara yang berjumlah 352 orang yang terdistribusi ke dalam 11 kelas. Pengambilan sampel dilakukan dengan teknik random sampling. Teknik random sampling ini digunakan karena anggota populasi relatif homogen (Sugiyono, 2008). Sampel yang diperoleh dengan teknik random sampling dinilai mantap karena memiliki tingkat kerepresentatifan tinggi yang mewakili populasinya. Berdasarkan teknik random sampling yang dilakukan, maka terpilih kelas VII E yang dikenai perlakuan model pembelajaran kooperatif tipe STAD berbantuan aplikasi google classroom sedangkan VII I yang dikenai perlakuan model pembelajaran PBL berbantuan aplikasi google classroom. Data-data yang dikumpulkan dalam penelitian ini adalah nilai keterampilan teknik dasar bola basket (dribbling, passing, shooting). Data hasil belajar bola basket peserta didik berupa kemampuan mempraktikkan peserta didik dikumpulkan dengan tes unjuk kerja.

Data dianalisis secara deskriptif dan Analysis of Varian (ANAVA). Analisis deskriptif digunakan untuk dapat mendeskripsikan nilai rata-rata siswa, simpangan baku pemahaman konsep, dan sikap ilmiah siswa. Pengujian hipotesis penelitian ini menggunakan ANAVA satu jalur. Sebelum pengujian hipotesis, terlebih dulu dilakukan uji normalitas sebaran data dengan menggunakan statistik Kolmogorov-Smirnov dan Shapiro-Wilk, uji homogenitas varian antar kelompok menggunakan Levene's Test of Equality of Error Variance, uji homogenitas matrik varian antar kelompok menggunakan uji Box's $M$, dan uji kolinieritas variabel terikat menggunakan uji korelasi Product Moment. Uji komparasi signifikansi nilai rata-rata menggunakan Least Significant Difference. Semua pengujian hipotesis dilakukan pada taraf signifikansi 0,05 yang dianalisis dengan bantuan program SPSS 16.0 PC for Windows dan Microsoft Excel 2007.

\section{HASIL DAN PEMBAHASAN Hasil}

Dari hasil analisis data diperolehlah data deskriptif statistik untuk kedua kelompok seperti pada tabel 1.

Tabel 1. Deskriptif Statistik Pada Masing-Masing Kelompok Belajar

\begin{tabular}{cccc}
\hline Kelompok & Mean & $\begin{array}{c}\text { Std. } \\
\text { Deviation }\end{array}$ & N \\
\hline 1 & 86.2222 & 1.35459 & 36 \\
2 & 81.8056 & 1.09073 & 36 \\
Total & 84.0139 & 2.53701 & 72 \\
\hline
\end{tabular}

Pada tabel diatas rata-rata hasil belajar teknik dasar bola basket kedua kelompok sangat berbeda. Kelompok yang dibelajarkan dengan model pembelajaran kooperatif tipe STAD berbantuan aplikasi google classroom menghasilkan rata-rata nilai yaitu 86,2 lebih tinggi dibandingkan kelompok yang lain. Kelompok yang dibelajarkan dengan model pembelajaran PBL berbantuan aplikasi google classroom menghasilkan rata-rata nilai yaitu 81,8 . 
Jadi kelompok yang dibelajarkan dengan model pembelajaran kooperatif tipe STAD berbantuan aplikasi google classroom mengalami peningkatan yang signifikan.

Tabel 2. Hasil Analisis Uji Normalitas Data Hasil Belajar Teknik Dasar Bola Basket

One-Sample Kolmogorov-Smirnov Test

\begin{tabular}{llr}
\hline & & $\begin{array}{r}\text { Standardized } \\
\text { Residual for } \mathbf{y}\end{array}$ \\
\hline $\mathrm{N}$ & & 72 \\
Normal Parameters $^{\mathrm{a}}$ & Mean & 84.0139 \\
& Std. & 2.53701 \\
& Deviation & .108 \\
Most Extreme & Absolute & .103 \\
Differences & Positive & -.108 \\
& Negative & .919 \\
Kolmogorov-Smirnov Z & .367 \\
Asymp. Sig. (2-tailed) & & \\
\hline
\end{tabular}

Hasil pengujian normalitas data menggunakan statistik KolmogorovSmirnov menunjukkan bahwa nilai-nilai statistik yang diperoleh 0,367 . Memiliki angka signifikansi lebih besar dari 0.05 . Hal ini menunjukkan bahwa sebaran data hasil belajar teknik dasar bola basket peserta didik berdistribusi normal. Hasil pengujian homogenitas varian mengunakan Levene's Test of Equality of Error Variances menunjukkan angka sebesar 0,339. Hal ini menunjukkan bahwa varian antar model pembelajaran adalah homogen.

Tabel 3. Hasil Analisis Uji Homogenitas Data Hasil Belajar Teknik Dasar Bola Basket

\section{Levene's Test of Equality of Error}

\begin{tabular}{cccc}
\multicolumn{4}{c}{ Variances $^{\mathrm{a}}$} \\
\hline F & df1 & df2 & Sig. \\
\hline .926 & 1 & 70 & .339 \\
\hline
\end{tabular}

Hasil pengujian hipotesis menyatakan bahwa terdapat perbedaan hasil belajar bola basket pada siswa yang dibelajarkan menggunakan model pembelajaran kooperatif tipe STAD berbantuan aplikasi google classroom dengan siswa yang dibelajarkan menggunakan model pembelajaran PBL berbantuan aplikasi google classroom. Pengujian hipotesis menggunakan rumus Independent Samples Test. 
Tabel 4. Hasil Analisis Menggunakan Uji t

Independent Samples Test

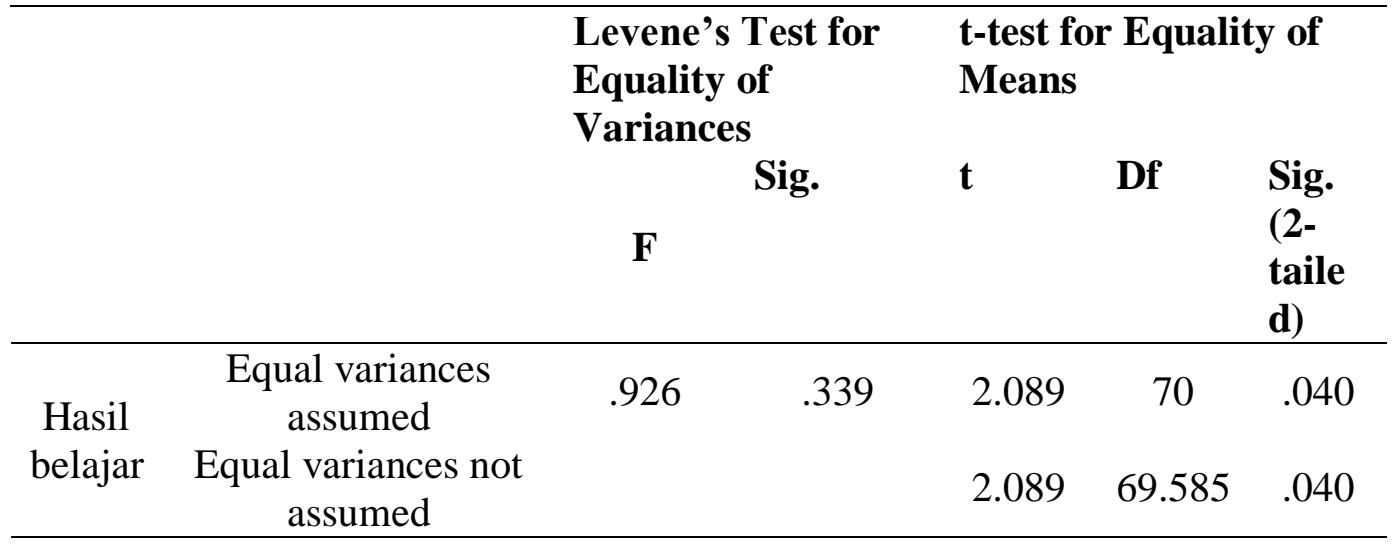

Berdasarkan hasil analisis dengan menggunakan metode statistik ANAVA dengan bantuan aplikasi SPSS diperoleh hasisl sebesar 0,040. Ini bermakna terdapat perbedaan hasil belajar bola basket antara siswa yang dibelajarkan menggunakan model pembelajaran kooperatif tipe STAD berbantuan aplikasi google classroom dengan siswa yang dibelajarkan menggunakan model pembelajaran PBL berbantuan aplikasi google classroom.

\section{Pembahasan}

Hasil uji hipotesis dalam penelitian ini di dapat nilai $\mathrm{F}$ sebesar 0,040 dengan signifikansi pada $<0,05$ sehingga nilai $F$ signifikan yang menyatakan model pembelajaran kooperatif tipe STAD berbantuan aplikasi google classroom berpengaruh terhadap hasil belajar bola basket, hasil tersebut dikarenakan bahwa dengan model pembelajaran kooperatif tipe STAD berbantuan aplikasi google classroom lebih baik dalam meningkatkan hasil belajar bola basket (dribbling, shooting, passing), dibandingkan dengan model pembelajaran PBL berbantuan aplikasi google classroom.

Dalam penelitian ini masing-masing kelompok diberikan perlakuan yang berbeda, yaitu satu kelompok diberikan model pembelajaran kooperatif tipe STAD berbantuan aplikasi google classroom dan satu kelompok lagi diberikan model pembelajaran PBL berbantuan aplikasi google classroom. Pembelajaran kooperatif tipe STAD menghendaki siswa bekerja saling membantu dalam kelompok kecil. Struktual tim beranggotakan 4-5 orang tiap kelompok dan menjalankan proses pembelajaran yang inovatif. Dalam pembelajaran kelompok yang dibelajarkan menggunakan model pembelajaran PBL peserta didik belum sepenuhnya memahami materi yang diberikan oleh guru. Peserta didik masih ragu dalam mencari masalah yang diberikan oleh guru.

Berdasarkan hasil peneliti pada saat pembelajaran berlangsung di masingmasing kelompok, pada kelompok yang diberikan model pembelajaran kooperatif tipe STAD berbantuan aplikasi google classroom pembelajaran diarahkan untuk peserta didik menerima materi dengan baik dan benar serta mengemukakan pendapat atau hasil yang sudah dipelajari bersama kelompoknya. Aktivitas peserta didik yang lebih positif dalam menelaah materi suatu pelajaran pada kegiatan belajar menjadi salah satu faktor yang membuat rata-rata skor yang diperoleh 
siswa pada kelompok diberikan model pembelajaran kooperatif tipe STAD berbantuan aplikasi google classroom lebih besar dari pada rata-rata skor yang diperoleh siswa pada kelompok lagi diberikan model pembelajaran PBL berbantuan aplikasi google classroom. Hal ini sejalan dengan teori Trianto dan teori Slavin tentang model pembelajaran kooperatif tipe STAD menyatakan bahwa model pembelajaran kooperatif merupakan model yang mengkondisikan siswa bekerja bersama untuk memperoleh tujuan bersama dalam kelompok-kelompok kecil dengan tingkat kemampuan yang berbeda-beda.

Hasil peneilitian ini didukung dengan penelitian,1) Haryanto (2015) menemukan bahwa, terdapat pengaruh yang signifikan penerapan model pembelajaran kooperatif tipe STAD berbantuan video animasi terhadap hasil belajar siswa kelas VII SMPLB C Negeri denpasar. Hal ini ditunjukkan dengan nilai thitung lebih besar dari pada $\mathrm{t}$ tabel $(\mathrm{t}$ hitung $=2,586>$ ttabel $=$ 2,262). 2) Roby (2013) menemukan bahwa, terdapat pengaruh yang signifikan implementasi model pembelajaran kooperatif tipe STAD berbantuan media VCD terhadap motivasi belajar siswa kelas V SD CHIS Denpasar dengan hasil uji hipotesis 1 nilai $\mathrm{F}$ hitungs ebesar 4,403 dengan probabilitas 0,042 . Ini berarti signifikansi berada di bawah 0,05.3) Swadesi (2018) menemukan bahwa, terdapat peningkatan kualitas pembelajaran dengan menggunakan media pembelajaran PJOK berbasis ICT di SMP, hasil yang menunjukkan bahwa uji coba model pembelajaran iniefektif dengan nilai skor rata-rata 4,349 (skala 5) dan dikategorikan "Sangat Baik". Data ini mencerminkan bahwa pemanfaatan ICT berperan penting terhadap kualitas pembelajaran. 4)
Yudani (2016) menemukan bahwa, terdapat peningkatan hasil belajar IPA setelah diterapkan model pembelajaran Problem Based Learning (PBL) berbantuan media Questions Box pada siswa kelas IV semester II di SD Negeri 4 Tulamben. Pada siklus I persentase hasil belajar siswa sebesar $71 \%$ yang berada dikategori sedang, dan pada siklus II persentase hasil belajar siswa meningkat menjadi $85 \%$ yang berada pada kategori tinggi. 5) Fatoni (2016) menemukan bahwa, terdapat pengaruh Pembelajaran Kooperatif Tipe STAD dengan Strategi Problem Based Learning Terhadap Kerjasama dan Hasil Belajar IPS Siswa Kelas V SD, berdasarkan hasil pretest kelas kontrol diperoleh rata-rata skor 59,3, simpangan baku 5,9 dan variansi 34,1. Untuk posstest rata-rata skor 68,5 simpangan baku 5,3 dan variansi 68,5. Sedangkan untuk kelas eksperimen diperoleh ratarata skor 72,3 simpangan baku 7,64 dan variansi 58,4 . Untuk posstest, rata-rata skor 81,2 simpangan baku 6,88 dan variansi 47,28. 6) Novriyanti (2014), menemukan bahwa, terdapat pengaruh model pembelajaran Problem Based Learning terhadap hasil belajar siswa pada materi pokok suhu dan kalor di kelas X SMA Negeri 1 Delitua, dengan nilai rata-rata posttest kelas eksperimen 71,63 dan kelas kontrol 67,48. Setelah data posttest normal dan homogeny dilakukan uji beda nilai kedua kelas diperoleh bahwa ada pengaruh model pembelajaran Problem Based Learning masalah terhadap hasil belajar siswa pada materi pokok suhu dan kalori di kelas X SMA Negeri 1 Delitua.

Berdasarkan hasil penelitian, model pembelajaran PBL berbantuan aplikasi google classroom yang diterapkan di kelompok kontrol pada dasarnya telah menuntun siswa untuk dapat memahami dan mempraktikan gerakan dengan benar. Namun penerapan model 
pembelajaran PBL berbantuan aplikasi google classroom ini dengan memberikan masalah terlebih dahulu para peserta didik masih kebingungan untuk memecahkan masalah yang diberikan oleh guru. Hal ini mengakibatkan kurangya partisipasi peserta didik secara menyeluruh dalam proses belajar mengajar. Hal ini berbeda dengan pembelajaran pada kelompok yang diberikan model pembelajaran kooperatif tipe STAD berbantuan aplikasi google classroom dimana siswa yang yang dibelajarkan melalui kelompok-kelompok kecil yang semua kelompok diberikan kuis pada masingmasing kelompok untuk menjelaskan hasil diskusi kelompoknya. Hal tersebut dapat peserta didik lebih cepat memahami materi yang diajarkan sehingga akan melibatkan partisipasi seluruh siswa. Faktor-faktor tersebutlah yang mengakibatkan pembelajaran yang berlangsung di kelompok yang diberikan model pembelajaran kooperatif tipe STAD berbantuan aplikasi google classroom mendapat respon yang lebih baik dari kelompok yang diberikan model pembelajaran PBL berbantuan aplikasi google classroom.

\section{SIMPULAN DAN SARAN \\ Simpulan}

Berdasarkan hasil pengujian hipotesis dan pembahasan dapat disimpulkan: 1) terdapat perbedaan hasil belajar teknik dasar bola basket antara kelompok yang dibelajarkan dengan model pembelajaran kooperatif tipe STAD berbantuan aplikasi google classroom dengan kelompok yang dibelajarkan dengan model pembelajaran PBL berbantuan aplikasi google classroom.

\section{Saran}

1) Disarankan kepada guru untuk dapat meneruskan atau menerapkan model pembelajaran kooperatif tipe STAD berbantuan aplikasi google classroom dan model pembelajaran PBL berbantuan aplikasi google classroom sehingga dapat meningkatkan hasil belajar peserta didik

2) Kepada peneliti yang lain disarankan untuk melakukan penelitian yang lebih mendalam dan meluas pada mata pelajaran PJOK.

\section{DAFTAR PUSTAKA}

Adiwiguna. 2019. Pengaruh Model Problem Based Learning (PBL) Berorientasi Stem Terhadap Kemampuan Berpikir Kritis Dan Literasi Sains Siswa Kelas V SD Di Gugus I Gusti Ketut Pudja. Jurnal Pendas Vol 3, No.2

Dewi. Kadek Arie Kusuma. 2018. Pengaruh Penerapan Model Pembelajaran Kooperatif Tipe Student Teams Achievement Division (STAD) Dan Bentuk Assessment Kinerja Terhadap Keterampilan Proses Tik Untuk Siswa Kelas Viii Di Smp Negeri 1 Kuta. Vol 8, No.2

Dimiyati dan Mudjiono. 2006. Belajar dan Pembelajaran. Jakarta: Rineka Cipta.

Emzir. 2008. Metodologi Penelitian Pendidikan. Jakarta: PT RajaGrafindo Persada

Fatoni 2016. "Pengaruh Pembelajaran Kooperatif Tipe STAD dengan Strategi Problem Based Learning Terhadap Kerjasama dan Hasil Belajar IPS Siswa Kelas V SD” Jurnal IPS (Hal 8491. Vol 2) 
Haryanto. 2015. Pengaruh Model Pembelajaran Kooperatif Tipe Stad Berbantuan Video Animasi Terhadap Hasil Belajar Ipa Dan Kreativitas Siswa Smplb C Negeri Denpasar. Jurnal Penelitian dan Evaluasi Pendidikan. Vol 5, No.1

Lestari, Seni. 2018. Pengaruh Model Pembelajaran Berbasis Masalah Terhadap Hasil Belajar Matematika Ditinjau Dari Kemampuan Berpikir Kritis Siswa Kelas Iv Sekolah Dasar Di Gugus I Kecamatan Buleleng. Jurnal Pendas. Vol 2, No.1

Muhajir, dkk. 2014. Buku Guru Pendidikan Jasmani Olahraga dan Kesehatan. Kementrian Pendidikan dan Kebudayaan. Jakarta

Novriyanti 2014. "Menemukan bahwa, terdapat pengaruh model pembelajaran Problem Based Learning terhadap hasil belajar siswa pada materi pokok suhu dan kalor di kelas X SMA Negeri 1 Delitua. Jurnal IPA

Permendikbud Republik Indonesia 22 tahun 2016 tentang standar proses pendidikan dasar dan menengah. 2016. Jakarta: Menteri Pendidikan dan Kebudayaan Republik Indonesia.

Prakoso. 2017. Pengaruh Metode Latihan dan Daya Tahan Otot Tungkai terhadap Hasil Peningkatan Kapasitas Vo2 max Pemain Bola Basket. Vol 5, No. 2

Purbarani. 2018. Pengaruh Problem Based Learning Berbantuan Media Audio Visual Terhadap Kemampuan Berpikir Kritis Dan Hasil Belajar Ipa Di Sekolah Dasar. Vol 2, No.1
Ratumanan Tanwey Gerson. 2002. Belajar dan Pembelajaran. Surabaya: Unesa University Press.

Rayanda, $\quad 2012$. Mengembangkan Media Pembelajaran. Jakarta :Gaung Persada (GP) Press Jakarta

Rusman. 2012. Model-model Pembelajaran. Jakarta:RajawaliPers

Rusman, Deni Kurniawan dan Cepi Riyana, Pembelajaran Berbasis Teknologi Informasi dan Komunikasi, (Jakarta: Raja Grafindo Persada, 2013), h. 169.

Slavin, Robert E. 2005. Cooperative Learning. Teori, Riset, and Praktik Bandung: Penerbit Nusa Media.

Sudiasih. 2018. Pengaruh Model Pembelajaran Pembelajaran Berbasis Masalah Berbantuan Media Konkrit Terhadap Hasil Belajar Matematika Ditinjau Dari Disposisi Matematika. Vol 2, No. 2

Sumantri, Syarif. 2015. Strategi Pembelajaran. Jakarta. RajawaliPers

Sumargi. 2015. Pengaruh Model Pembelajaran Kooperatif Tipe Stad Terhadap Motivasi Belajar Dan Prestasi Belajar Ipa Siswa Kelas Vi Sd Negeri 3 Bedulu Tahun Pelajaran 2013/2014. Vol 5, No.1

Sriwulan. N. Ariani. 2014. Pengaruh Model Pembelajaran Kooperatif Tipe Student Teams Achievement Division (Stad) Terhadap Kemampuan Membaca Wacana Bahasa Jepang Dengan Kovariabel Tingkat Kecemasan 
Siswa Kelas Xii/Ipb Sma Negeri 1

Semarapura. Vol 4, No.1

Swadesi. 2018. Pengembangan Media Pembelajaran PJOK Berbasis ICT di SMP. Jurnal Undiksha.

Trianto. 2007. Model-model

Pembelajaran inovatif Berorientasi Konstruktivistik. Jakarta. Prestasi Pustaka.

Wijaya, Made Agus. 2015. Developing Fundamental Movement Based Cooperative Learning Model In Primary School. Jurnal Undiksha Vol 2, No. 1

Wirata. 2019. Penerapan Model Pembelajaran Problem Based Learning Untuk Meningkatkan Prestasi Belajar Ipa Siswa. Vol 3, No.9

Yudiani. 2016. Penerapan Model Pembelajaran PBL Berbantuan Media Questions Box Untuk Meningkatkan Hasil Belajar IPA Siswa. Jurnal PGSD. Vol 4, No 1 